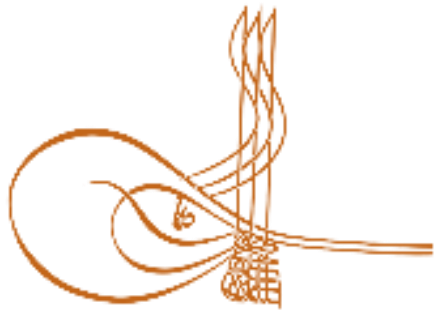

www.turkishstudies.net/social
Turkish Studies - Social Sciences

eISSN: $2667-5617$

Research Article / Araşttrma Makalesi

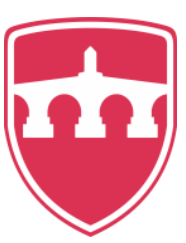

INTERNATIONAL

BALKAN

UNIVERSITY

Sponsored by IBU

\title{
Etik Liderliğin İşten Ayrılma Niyeti Üzerindeki Etkisinde Algılanan Örgütsel Adaletin Aracılık Rolü
}

\author{
Mediator Role of Perceived Organizational Justice in the Effect of Ethical Leadership on Turnover \\ Intention
}

Ebru Beyza Bayarçelik*

\begin{abstract}
In this study, it is investigated how the ethical behaviors of managers affect the perceived climate of justice and intentions to quit by the employees. The aim of this study is find out the mediator role of employees' perceived organizational justice in the effect of managers' ethical leadership behaviors on intention to leave in Banking industry. As these relationships are investigated, ethical leadership, organizational justice, intention to quit and their sub-dimensions are explained respectively. Banking is one of the service sectors that is quickly affected by changes such as globalization and technology so research data were collected through questionnaires among 390 banking sector employees who were reached by convenience sampling. In order to measure the concepts, 'Ethical Leadership Scale' of Brown, Trevino and Harrison (2005), 'Organizational Justice Scale' by Niehoff and Moorman (1993), and Grandey's (1999) scale for the 'Intention to Quit' are employed in the research. Research model and hypothesis were tested using the structural equality modeling. To test the measurement model, 4 factored confirmatory factor analysis was conducted and the results show that the compatibility of the model is considerably good. Research findings shows ethical leadership has a direct and significant effect on distributive and interactional justice and decrease the intention to quite. In addition, the leader's ethical behavior decrease employees' intention to quit through the perception of justice that they perceive within the organization. Both the distributive justice and the interaction justice has a role of full mediating variable between ethical leadership and quitting intentions.
\end{abstract}

Structured Abstract: In the $4^{\text {th }}$ Industrial Era, while everything changes rapidly and despite the fact that access to information is easier yet how it could make a difference is still under research, every business is affected by the changes occurring around it. In such an environment, companies who try to differentiate themselves and to sustain a competitive advantage must adapt to the changing environmental conditions. Despite all the changes, the true competitive source of the businesses is still their human resources. The need to mobilize and manage the human resources in accordance to the organization's targets and objectives and to establish a positive bond with the organization necessitates a leader. Organizational justice is crucial for the leaders, as justice culture

\footnotetext{
* Dr. Öğr. Üyesi, Maltepe Üniversitesi, İşletme ve Yönetim Bilimleri Fakültesi, Uluslararası Ticaret ve Lojistik Yönetimi Asst. Prof. Dr., Maltepe University, Faculty of Business and Management Sciences, International Trade and Logistics Management.

ORCID 0000-0003-4886-5719

ebrubeyzabayarcelik@maltepe.edu.tr

Cite as/ Atıf: Bayarçelik, E.B. (2020). Etik liderliğin işten ayrılma niyeti üzerindeki etkisinde algılanan örgütsel adaletin aracilık rolü, Turkish Studies - Social, 15(2), 31-50. https://dx.doi.org/10.29228/TurkishStudies.40083

Received/Geliş: 09 December/Aralık 2019

Accepted/Kabul: 25 February/Şubat 2020

Checked by plagiarism software

Copyright $($ INTAC LTD, Turkey 
could only be established when it is dissolved fully into the management process and into the management philosophy of the organization.

In the literature, the relations between ethical leadership, organizational justice and intention to quit among various sectors are under growing interest of further researches (Erdoğan-Arac1, 2019; Yanık and Naktiyok, 2017; Lam, et al., 2016; Palanski, et al., 2014; Yoldaş, 2018; Çitak, 2017; Akatay et al., 2016; İnak, 2016; Turan, 2015). As ethical leadership, organizational justice and intention to quit were used to be evaluated in binary, The aim of this study is find out the mediator role of employees' perceived organizational justice in the effect of managers' ethical leadership behaviors on intention to leave in Banks. Therefore this study hopefully contributes to the body of studies in the field of ethical leadership, organizational justice and intention to quit.

Daft and Marcic (1998: 420) defines leadership as the ability to mobilize and to influence the members of an organization by efficiently employing the power at hand. In the concept of ethical leadership, behaving ethical in the work place is an obligation and responsibility (MacIntyre, 2001: 97). Ethical leadership explains how the ethical behavior of the leader affects the ethical choices and behavior of its followers.

Masterson et al. (2000) defines organizational justice as following the right distribution procedures by the organization leaders in terms of reward, promotion, salary and other institutional output. Organizational justice is about whether the employees consider the treatments as just, how they make their concept of justice, and furthermore how these decisions affect other variables in the whole (Moorman, 1991: 845). In this regard organizational justice is manifested as the distribution of acquisitions, the processes needed for the decision on distribution and the rules developed for the interpersonal applications such as social norms. The widest accepted classification in the literature is the distributive justice, Procedural justice and interaction justice (İyigün, 2012). Distributive justice is about whether the benefits, often the material benefits fruiting from the employees' labor are distributed justly (Giap and Hackermeier, 2005). Distributive justice explains the fact that the administration distributes rewards, punishment or resources in line with given criteria as well as the reactions of the individuals to the consequences of this distribution. Procedural justice includes the decision making processes and its applications (Bal-Taştan, 2013: 468). Interaction justice focuses on the employees and their communication. Interactional justice, however, represents the perceptions of the individuals in regard to the quality of behaviors they confront while the organizational procedures are being applied. Iteractional justice also focuses on the interaction between the managers and the employees within the same organization (Folger and Konovsky, 1989).

Intention to quit is the conscious and deliberate decision of an employee to leave the organization. As the studies demonstrate, intention to quit occurs as a pioneer to the act of quitting.

Population of the research is the public and private banks in İstanbul region. Non-probablistical type of sampling as convenience sampling was employed in the research with 390 participants. In the study, 'Ethical Leadership Scale' consisting of 10 articles developed by Brown, Trevino and Harrison (2005) was used. In order to measure the organizational justice evaluations of the employees, 'Organizational Justice Scale' developed by Niehoff ve Moorman (1993) was employed. The survey consists of 15 questions which 5 of them is about distributive justice 10 of item is about Interactional justice. Grandey's (1999) 'Intention to Quit' scale was used in order to determine the quitting intentions of the employees. For testing the research hypotheses, structural equation modeling was employed, in which Hu and Bentler's (1999) suggestions were taken as a basis in both the measurement and evaluation of the structural model adaptive values. For the construct validity, convergence and difference validity tests were realized.

It is observed that the adaptive values are considerably $\operatorname{good}\left(\chi^{2}=704.201, \mathrm{df}=270 ; \mathrm{CFI}=.945\right.$; $\mathrm{TLI}=.939, \mathrm{RMSEA}=.066 \mathrm{SRMR}=.059)$. Total declared variant $(\mathrm{R} 2)$ is found to be $31 \%$ in the intention to quit variable, $31 \%$ in distributive justice variable and $66 \%$ in transaction variable. According to the conclusion of the model, ethical leadership has a significant and direct effect on the distributive justice $(\beta=.56, \mathrm{SH}=.050$, $\mathrm{p}<.001)$ and the interactional justice $(\beta=.81, \mathrm{SH}=.044, \mathrm{p}<.001)$, however have not significant and direct effect on the intention to quit $(\beta=.07, \mathrm{SH}=.102, \mathrm{p}=.49)$. Therefore $\mathrm{H}_{2} \mathrm{a}$ and $\mathrm{H}_{2} \mathrm{~b}$ was accepted. Furthermore, both the distributive justice $(\beta=-.32, \mathrm{SH}=.079, \mathrm{p}<.001)$ and the interactional justice $(\beta=-.39, \mathrm{SH}=.119, \mathrm{p}<.001)$ are found to have a significant and negative effects on the intention to quit. Thus $\mathrm{H}_{3}$ a and $\mathrm{H}_{3} \mathrm{~b}$ was accepted. It is also found that the total indirect effect of ethical leadership to the intention to quit and from the distributive and interactional justice is meaningful $(\gamma=-.50, \mathrm{SH}=.076,95 \% \mathrm{GA}=-.65:-.35)$. When the indirect effects of the two 
paths were scrutinized, ethical leadership is found to be significant in terms of indirect effects, both through the distributive justice $(\gamma=-.19, \mathrm{SH}=.045,95 \% \mathrm{GA}=-.29$ :-. 11$)$ and the interactional justice $(\gamma=-.34, \mathrm{SE}=.087$, 95\% GA=-.51:-.17). These results are showing that both the distributive justice and the interactional justice act as full mediating variables. Therefore the fourth hypothesis was accepted.

As a result of the analyses, it is observed that ethical leadership has a positive effect on the perception of both the distributive justice and the interactional justice, and also displays a decrease in the intention to quit among the employees depending on the justice perception created by the ethical leader. Providers of a just environment in the organization are the managers of that organization. Behavior of the managers, their attitude towards their subordinates, sharing and distributing the resources and rewards raise the employees' perception of justice and positive emotions, therefore decreases the intention to quit. Studies in the literature indicate that ethical leaders constitute justice in the organization through their display of ethical behavior roles (Uğurlu, 2009, Yildırım 2010). Besides, leadership behavior also has a considerable effect on the employees' intention to quit. A study by Telli et al. (2012: 143) concludes that in the cases of employees with a positive opinion on their leader, their intention to quit decreases. In this study, there are also some limitations such as only the banking sector was evaluated. In further research, different sectors of services and production should be evaluated together in comparison. The study could be repeated in different time periods. In order to conceive ethical leadership further and also to detect cultural differences, cross-cultural research could be conducted.

Keywords: Ethical Leadership, Perceived Organizational Justice, Intention to Leave

Öz: Bu çalışmada, yöneticilerin etik davranışlarının çalışanların algıladıkları adalet iklimini ve işten ayrılma düşüncelerini, nasıl etkilediği araştırılmaktadır. Çalışmanın amacı, bankada çalışan yöneticilerin etik liderlik davranışlarııın çalışanların işten ayrılma niyetlerine etkisini ve örgütsel adalet algılarının bu etkide oynadığı aracılık rolünü incelemektir. Bankacılık, küreselleşme ve teknoloji gibi değişimlerden hızlıca etkilenen hizmet sektörlerinden biridir. Bu ilişkileri incelerken sırası ile etik liderlik, örgütsel adalet ve ișten ayrılma niyeti ve alt boyutları açıklanmıştır. Araştırmanın verileri anket yöntemiyle toplanmış ve İstanbul'da bankacılık sektöründe çalışan 390 kişiye kolayda örnekleme methodu kullanılarak ulaşılmıştır. Çalışmada etik liderliği ölçmek için Brown, Trevino ve Harrison'ın (2005) “Etik Lidelik Ölçeği”, örgütsel adaleti ölçmek için Niehoff ve Moorman'ın (1993) “Örgütsel Adalet Ölçeği” ve “İşten Ayrılma Niyeti'ni” ölçmek için Grandey'in (1999) geliştirdiği ölçekler kullanılmıştır. Araştırma modeli ve hipotezler yapısal eşitlik modellemesi kullanılarak analiz edilmiştir. Ölçüm modelini test etmek için dört faktörlü doğrulayıcı faktör analizi yapılmıştır ve sonuçlar modelin uyumunun oldukça iyi olduğunu göstermiştir. Araştırma bulguları etik liderliğin hem dağııım adaleti hem de ektileşim adaleti üzerinde anlamlı direkt etkisinin bulunduğunu ve çalışanların işten ayrılma niyetini azalttığını ortaya koymuştur. Ayrıca liderin etik davranışlar sergilemesi çalışanların işten ayrılma niyetlerini örgüt içinde algıladıkları adalet algısı aracılığı ile azaltmaktadır. Araştırma sonuçları hem dağıtım adaletinin hem de etkileşim adaletinin tam aracı değişken görevi gördüğünü göstermektedir.

Anahtar Kelimeler: Etik Liderlik, Algılanan Örgütsel Adalet, İşten Ayrılma Niyeti

\section{Giriş}

Herşeyin çok hızlı değiştiği, bilgiye ulaşmanın kolaylaşmasına karşın, nasıl fark yaratacağı konusunun halen araştırıldığı 4 . Endüstri çağında tüm işletmeler dış çevresinde meydana gelen değişimlerden etkinlenmektedirler. $\mathrm{Bu}$ ortamda kendini farklılaştırmak ve sürdürülebilir rekabet üstünlüğü elde etmeyi amaçlayan işletmeler, adaptasyon teorileri gereğince değişen çevre koşullarına uyum sağlamak zorundadır. Tüm değişimlere karşın işletmelerin değişmeyen rekabet gücünün esas kaynağı olan insan kaynağıdır. İnsan kaynağının örgüt hedef ve amaçları doğrultusunda harakete geçirilip yönetilebilmesi, örgüt ile olumlu bağ kurabilmesi, lider ihtiyacını ortaya çıkarmaktadır. Liderler, örgütsel politikaların, düzenlemelerin ve prosedürlerin geliştirilmesi ve uygulanmasını adaletli hale getirerek örgütsel adalet yönetimini örgüt içinde kurmakla sorumludur. Örgütsel adalet liderler için önemlidir çünkü adalet bir örgütün yönetim felsefesinin temel değeri olarak tüm yönetim sürecine yayıldığı zaman adalet kültürü oluşabilmektedir. 
Amerika Birleşik Devletlerinde Enron ve Çin'de Sanlu Sütlerinde yaşanan skandallar ve diğer etik dışı davranışlar, etik kavramının iş dünyasında önemini ortaya çıkmaya başlamış bu bağlamada etik liderlik, akademik çalışmalarda daha sık merak edilen konuların arasına girmiştir (Xu, vd., 2016). Etik liderlik araştırmaları gün geçtik artmasının nedeni, çalışanın görev performansı ve örgütsel vatandaşlık davranışı ve etik olmayan davranışların azaltılması, işe bağlılık gibi örgütsel çıktılar ile bağlantılı olmasıdır (Lam, vd.,2016). Örgütsel adalet kavramı da, örgütlerde yaşanan değişimler sonucunda etik liderlik kadar önem kazanan bir diğer konudur. İşgörenlerin çalışma ortamında kaynakların dağılımından, ücretlendirmeye, kendilerine gösterilen davranış ve tutumlara kadar yöneticilerin ne derece adil davrandıklarını değerlendirilmektedir. Bu değerlendirme sonuçları çalışanların iş tutum ve davranışlarına; iş tatmini, örgütesel bağlılık ya da işten ayrılma niyeti olarak yansımaktadır (Gül, 2008).

Literatürde etik liderlik, örgütsel adalet ve işten ayrılma niyeti arasındaki ilişkilerin farklı sektör çalışanları ile giderek artan bir merakla araştırıldığ1 görülmektedir (Erdoğan-Aracı, 2019; Yanık ve Naktiyok, 2017; Lam, vd., 2016; Palanski, vd., 2014; Yoldaş, 2018; Çitak, 2017; Akatay vd., 2016; İnak, 2016; Turan, 2015). Daha önceki araştırmalarda ikili olarak ele alınıp, araştırılan etik liderlik, örgütsel adalet ve işten ayrılma niyeti bu çalışmada birlikte ele alınarak, yöneticilerin etik liderlik davranışlarının çalışanların işten ayrılma niyetlerine etkisini ve örgütsel adalet algılarının bu etkide oynadığ 1 aracılık rolünü ortaya koymayı amaçlamaktadır. Algılanan örgütsel adalet dağıtımsal adalet, işlemsel adalet ve etkileşimsel adalet boyutlarından oluşmaktadır. Dolayısıyla bu çalışmanın, etik liderlik ve örgütsel adalet ve işten ayılma niyeti alanında yapılan çalışmalara katkı sağlayacağı düşünülmektedir. Dağıtım adaletinin ve Etkileşim adaletinin sağlanmasında liderin direkt rolü ortaya çıkarken, İşlemsel adalet daha çok örgüt düzeyinde belirlenen prosedür ve yönetmelikler ile ilgilidir. Ayrıca lider-takipçi süreçleriyle yakından ilişkili olan etkileşimsel adalet boyutu örgütün içinde oluşacak adil iklimin yaratılmasında önemli bir yere sahiptir. Tüm bu bilgiler 1şında verilerin toplanabilmesi açısından soru sayısının çok olmaması gerektiğinden, parsimonius davranarak adalet ölçeğindeki işlemsel adalet soruları kullanılmadan araştırmaya devam edilmiştir.

\section{Kavramsal Çerçeve}

\subsection{Etik Liderlik}

Etik kelimesi Yunanca karakter anlamına gelmekte olan "ethos" kelimesinden türemiş olup (Yücel ve Çiftçi, 2012: 927), günümüzde ahlaki normlara uygun davranma manasına gelmektedir. Ahlak ile karşılaştırdığında etik, daha evrensel ve kapsayıcıdır (Helvacı, 2010: 392). Zira etik, ahlaka göre daha felsefi ve soyut bir kavramdır (Gül ve Gökçe, 2008: 379). Etik daha ziyade bir durumla ilgili olarak fertler arasındaki hak ve standartlar şeklinde belirtilmekte olup, bu standartlar ile adalet ve eşitlik içermekte olan genel kabul görmüş sosyal kurallar kastedilmektedir (Lu ve Lin, 2014: 210).

Liderlik kavramına ilişkin olarak literatür de pek çok farklı tanımlama ve görüş bulunmaktadır. Daft ve Marcic (1998: 420) liderliği, sahip olunan gücün etkin şekilde kullanılmas1 suretiyle örgütsel hedeflere erişilmesi hususunda örgüt üyelerinin etkilenmesi ve onların harekete geçirilmesine ilişkin kabiliyet şeklinde tanımlamıştır. Werner (1993: 17) ise liderlik kavramını; belli zamanlarda, belli şartlarda ve belli durumlarda örgütsel hedeflere erişmek üzere bireyleri kendi arzularıyla çaba sarf etmeye teşvik eden, belirlenmiş olan hedefe erişilmesi hususunda yol gösterebilen, bütün tecrübelerini aktarabilen ve uygulanan liderlik tipinden memnun olmalarını sağlayıcı etkileme süreci olarak betimlemiştir. Eren'e (2012: 435) göre liderliği, bir grup insanı belli amaçların etrafinda toplayabilme ve bu amaçlar hususunda organize olmuş grubu harekete geçirebilme yeteneği ve bilgilerinin toplamı şeklinde ifade etmiştir.

Etiğin yönetsel anlamdaki kullanımı etik liderlik düşüncesiyle olmaktadır. Son yıllarda etik liderlik araştırmacılar tarafından sıkça üzerinde çalışılmakta olan bir konudur. Etik liderlik anlayışında, işyerinde etik şekilde davranılması bir ödev ve sorumluluk niteliğindedir (MacIntyre, 2001: 97). Etik liderlik, işletmedeki liderin etik davranışlarının, takipçilerin etik kararları ve 
hareketlerini ne şekilde etkilemekte olduğunu açıklamaktadır. Etik liderlik teorisine göre liderler, takipçilerin etik kararlarıyla davranışlarını sosyal öğrenme teorisi, etik standartların önemi hususundaki iletişim, sosyal değişim süreçleri ve işgörenlerin ölçülebilir sonuçlarını performans yönetim sistemi vasıtasıyla etkilemektedir (Brown ve Trevino, 2006a: 955).

Brown ve arkadaşları (2005: 120) etik liderlik kavramını, bireysel aktivitelerde ve bireylerin arasında bulunan ilişkilerde normatif uygunluk içinde yönetim tarzını ortaya koyarken, bu tip yönlendirmeleri karşıllklı iletişim içinde, bireyleri güçlendirmek ve ahlaki düşünme hususunda yönlendirmek suretiyle etik liderlik özelliklerini arttırmayı hedefleyen bir liderlik tarzı şeklinde betimlemiştir. Van Gils vd. (2015: 191) etik liderliği, liderin etik davranışlarını sosyal öğrenme, sosyal mübadele, sosyal kimlik ve özdeşleşme aracılığıyla astlara aktarması süreci şeklinde tanımlamıştır.

Etik liderliğin temeli normatif yaklaşıma ve sosyal öğrenme teorisine dayanmaktadır. Zira etik liderlik, normatif yaklaşıma uygun olarak işyerinde nasıl davranılması gerektiği hususu üzerinde durmaktadır (Brown, 2007). Normatif yaklaşıma göre etik lider; adaletli, dürüst, prensipli ve güvenilir şekilde davranacak, ödül ve ceza sistemlerini etik davranışların motive edilmesi hususunda kullanacaktır (Piccolo vd., 2010: 261). Brown vd. (2005) ayrıca etik liderliği tanımlarken Bandura (1977) tarafından geliştirilen sosyal öğrenme teorisinden faydalanmıştır. Sosyal öğrenme teorisi, etik liderin takipçiler üzerinde ne şekilde bir etki bıraktığı ve takipçileri neden etkilemekte olduğunu açıklamaya yardımcı olmaktadır (Brown ve Trevino, 2006b: 597).

Etik liderlik yaklaşımının öncüsü olan Brown ve Trevino (2005) etik liderliğin dört boyutu bulunduğundan bahsetmiş ve bu boyutları etik iklim, etik karar verme, davranışsal etik ve iletişimsel etik şeklinde ifade etmişlerdir. Etik iklim, örgütün değerlerinin ne olduğu, ne tip davranışların uygun olduğu ve ne şekilde davranılması gerektiğini ifade etmektedir (Mayer vd., 2010: 9). Başka bir ifadeyle etik iklim, örgütte çalışan kişilerin etiğe ilişkin algıları olup, örgütün etik konularla ilintili hassasiyetinin çalışanlar tarafınca ne şekilde hissedildiği ile ilgilidir (Martin ve Cullen, 2006: 177). Etik karar verme, etik liderin doğru olanla olmayanı ayırt etmesi suretiyle, etik kurallarla uyumlu karar vermesi ve ardından bu kararla tutarlı olan davranışlarda bulunmasıdır (Turhan, 2007). Bir diğer ifadeyle etik karar verme, örgütü ilgilendirmekte olan muhtelif paydaşlarla potansiyel rakiplerin de menfaatlerinin tanınmasıyla ilgili yorumları gerektirmekte olan çok yönlü bir süreç olup, bu sürecin ahlaki gerekler doğrultusunda yürütülmesi gerekmektedir (Davies ve Crane, 2003: 81). Davranışsal etik, genel kabul görmüş olan ahlaki davranış normları doğrultusunda yargılanmakta olan bireysel davranış şeklinde ifade edilmektedir (Trevino vd., 2006: 952). İletişimsel etik ise, ahlaki değerlerin liderlerden astlara taşınması noktasında iletişimin rolünü vurgulayan boyuttur (Brown vd., 2005).

Etik liderlerin sahip olduğu birtakım özellikler mevcuttur. Kalshoven ve Boon (2015) etik liderlerin temelde yedi özelliği bulunduğundan bahsetmiş ve bu özellikleri; adalet, paylaşılan liderlik, görev ve rol belirlenip paylaşılması, özen, bakış açısı, etik davranışın ödüllendirilmesi ve dürüstlük şeklinde ifade etmiştir. Northouse'a (2012) göre etik liderlerde bulunması gereken özellikler ise diğerlerine saygı duymak, diğerlerine hizmet etmek, adalete ilişkin kaygı duymak, dürüstlüğ̈̈ savunmak ve birliktelik sağlamaktır. Harvey (2004: 23) ise etik liderlerin; etik değerlerle standartları dile getiren ve bunların anlaşılıp destekleyen, kabul edilmesi hususunda gerekeni yapan; kendileri ile beraber başkalarının da etik ilkelerle değerlere uygun davranmaları konusunda sorumluluk almalarını sağlayan; dürüst oldukları için, diğerlerinden de aynı şekilde dürüst davranmalarını bekleyen; karar verme noktasında gerçekleştirilen her bir işte etik değerleri ortaya koyabilen, ortaya koymuş oldukları kurallar etik değerleri destekleyen ve bu nedenle yaşanan sorunları da kısa zamanda çözebilen; meslektaşlarıyla işgörenlerin duyguları ile düşüncelerine dikkat eden, muhtelif alanlarda ve çok sayıda küçük iyileştirmeler gerçekleştiren; diğerlerine karşı yol gösteren, örgütte 
çalışan kişilerin işe alımları ve yükseltilmelerinde karar alırken belirleyecekleri kriterlerin de örgütün misyonunu, vizyonunu ve değerlerini göz önünde bulunduran özelliklere sahip olduğunu belirtmiştir.

\subsection{Algilanan Örgütsel Adalet}

Adalet, haklılıkla doğruluğun ifadesidir (Kaya, 2000: 232). Başka bir ifadeyle geri dönüşümle katkının eşit olmasıdır (Adair, 2003: 203). Adalet, toplumsal yaşamda düzenle dirliğin sağlanması ve hayat hususunda gereksinim duyulmakta olan muhtelif kaynakların paylaşımı noktasında temel bir ilke şeklinde vurgulanması gerekli olan bir kavramdır (Çelik ve Sarıtürk, 2012: 357-358). Adalet gerek bireysel, gerek sosyal açıdan yapılandırılmış, kişinin inancı ve etik tutumuyla biçimlenmektedir (Caldwell vd., 2001: 187). Ancak belirtmek gerekir ki, bireylerin ve grupların adalete ilişkin bilinçleri ve atfettikleri farklılık gösterebilmekte, bu doğrultuda adalete vermekte oldukları önem de farklılık gösterebilmektedir (Clayton ve Opotow, 2003: 33). Bireylerin toplumsal yaşam içerisinde birbiriyle uyumlu şekilde hayatlarını sürdürmeleri hususunda adalet vazgeçilmez bir unsur niteliğindedir. Bununla birlikte, toplumun bir parçası niteliğine sahip olan örgütler açısından da adalet olgusu önemli bir inceleme konusudur. Bu bağlamda, örgütlerde kaynaklar, kazanımlar, ödüllerle menfaatlerin korunması hususu örgütler açısından adalete olan ilgiyi arttırmış durumdadır (Çöp, 2008: 1).

Örgütlerin temel değerlerinden birisi adalettir (Konovsky, 2000: 490). Günümüz iş çevresinde bilginin örgütlerin önemli bir sermaye unsuru ve üretim faktörü olduğunun keşfedilmesi neticesinde, bilginin üreticisi konumundaki insanı ilgilendirmekte olan örgütsel adalete ilişkin bilimsel çalışmalar artış göstermiş̧ir (Efil, 2010: 78). Örgütlerde çalışanların kendi arasındaki etkileşimlerin sonuçlarının gittikçe önem arz etmesiyle beraber sosyal adalet konusu gündeme gelirken; bu bağlamda örgütlerin içerisindeki ilişkilere bağl1 şekilde beliren örgütsel ve kişisel her tür çıktının, ödülle cezanın adaletli biçimde dağıtılmasını belirtmekte olan örgütsel adalet kavramı ortaya çıkmaktadır (Charash ve Spector, 2001).

Literatürde örgütsel adaletle ilgili olarak yapılmış olan çeşitli tanımlamalar bulunmaktadır. Masterson vd. (2000) örgütsel adaleti, örgütlerdeki yöneticilerin ödül, terfi, ücret gibi pek çok kurumsal çıktıyı çalışanlara dağıtmaları sırasında doğru süreçleri izlemeleri şeklinde tanımlamıştır. Örgütsel adalet, işgörenlerin çalıştıkları örgütte kendilerine adaletli davranılıp davranılmadığına ne şekilde karar verdikleriyle ve bu kararların işe ilişkin diğer değişkenleri ne şekilde etkilediğiyle ilgili bir kavram olarak atfedilmektedir (Moorman, 1991: 845). Bu bağlamda örgütsel adalet, kazanımların dağıtımı, dağıtıma ilişkin kararlarının alınması noktasında yararlanılan işlemler ve bireyler arası uygulamalarla ilintili olarak geliştirilen kurallarla, sosyal normlar şeklinde ortaya çıkmaktadır (Folger ve Cropanzano, 1997). Bireylerim çalıştıkları örgütteki uygulamalara ilişkin olarak adalet algılaması şeklinde nitelendirilmekte olan örgütsel adalet, değişim gösteren çalışma yaşamıyla birlikte daha etkin bir hal almaya başladığ görülmektedir(Greenberg,1996: 24).

İşgörenler ücretlerle ödüllerin dağıtılma türü, terfiler, yöneticilerle iş arkadaşlarının davranışları vb. hususların ne denli adaletli olduğunu değerlendirirken, gerçekleşen adaletsizlik durumlarına muhtelif şekillerde tepki gösterebilmektedir. İşgörenler sahip oldukları örgütsel adalet bilincinin neticesinde çevrelerine yönelik olarak meydana getirdikleri birtakım tepkilere sahip olup, bu tepkilere sebebiyet veren adalet bilinciyse, yöneticilerinin kendilerine yönelik davranışlarında adaletli olma durumları, dağıtımı yapılan ödüllerin adaletli olup olmaması vb. durumlar ile belirlenmektedir (İyigün, 2012: 50).

Son yıllarda örgütsel adaletin giderek önem kazanmasının çeşitli nedenleri vardır. Bunlardan ilki, sosyal bir olgu niteliğindeki adaletin her tür sosyal, örgütsel ve gündelik hayattaki bireyler arası ilişkiler nezdinde ortaya çıkabilecek bir durum olmasıdır. Bu nedenle bireyler iş hayatında sıklıkla adaletin muhtelif türleriyle karşılaşmakta, iliş̧kilerinin sıklık durumuysa adalete duyulmakta olan gereksinmeyi günden güne artırmaktadır. İkinci neden, en önemli kaynağı işgörenler olan organizasyonların yönetime ilişkin süreçlerinin tamamında adalet algısının belirleyici durumda

Turkish Studies - Social, 15(2) 
olmasıdır. Bir örgütteki çalışanlara ne şekilde davranılmakta olduğu ve çalışanların örgütlerine olan bağlılığı, güveni, performansı, işten ayrılma niyeti ve saldırganlığı gibi tutumlarıyla davranışlarının tamamı örgütteki adalet algısından etkilenmektedir (Şahin ve Kavas, 2016: 121).

İşgörenlerin adaletli bir örgütte çalıştıklarına yönelik bilinçleri; iş arkadaşlarına yardımcı olma, mevcut sorumlulukları doğrultusunda rollerinin ötesinde pozitif davranışlarda bulunma, örgütte huzursuzluğa yol açabilecek negatif davranışlarla çatışma içerisinde bulunmaktan kaçınma ve örgütteki süregelen hayata katılma gibi gönüllülük temelli davranışlarını pekiştirmektedir (Çetinkaya ve Çimenci, 2014: 252 ).

Pozitif örgütsel adalet bilinci insanları pozitif davranışlara yöneltmekteyken, negatif örgütsel adalet bilinciyse saldırganlık, hırsızlık gibi negatif tepkiler yaratması suretiyle örgütleri zor durumlara sokabilmektedir (Beugre, 2002: 1092). Adaletin olmadığı örgütlerde çalışan kişilerin örgütlerine yönelik bağl1lı̆̆ azalma göstermekte ve netice itibariyle işten ayrılmaya yönelmektedirler. $\mathrm{Bu}$ sebeple yöneticilerin örgütsel adaletin önemini bilmeleri gerekli olup, işgörenlerin bir adaletsizlik halinde verecekleri tepkileri öngörebilmelerinde yarar bulunmaktadır. Zira örgütsel adalet algısı işgörenlerin arasındaki işbirliğini kolaylaştırıcı bir etkide bulunmaktadır (Söyük, 2007: 7).

Örgütsel adaletin boyutları hususunda yapılmış olan çeşitli çalışmalar bulunmakla birlikte, literatürde en çok kabul görmüş olan sınıflandırma dağıtımsal adalet, işlemsel adalet ve etkileşimsel adalet şeklindedir (İyigün, 2012). Dağıtımsal adalet alınan kararların neticelerine (Bal-Taştan, 2013: 468) ve işgörenlerin elde ettikleri çıktıların adilliğinin algılanmasına ilişkindir. Bu doğrultuda dağıtımsal adalet; cezalarla ödüller, ücretler, statüler, terfiler gibi çıtıların bireyler arasındaki paylaşımıyla işgörenlerin bu çıktıların adilliğine yönelik algılamalarını ifade etmektedir (Greenberg, 1990: 400). Dağıtımsal adalet, çalışanların gerçekleştirdikleri işlerin neticesinde edindikleri daha ziyade maddi çıkarla ölçülen menfaatlerinin adaletli biçimde dağıtıldığına ilişkin inançlarına odaklanır (Giap ve Hackermeier, 2005). Işslemsel (prosedür) adalet, örgütteki karar alma süreçleriyle uygulamalarını içermektedir (Bal-Taştan, 2013: 468). İşlemsel adalet, kazanımların neye göre ve nasıl belirlendiğini, kazanımların dağıtımında kullanılan karar verme mekanizmasının nasıl işlediğini, fazla ya da eksik ödemeden kaçınma, neticelere ilişkin bilgi verme vb. örgütsel prosedürlerin işgörenler arasında eşit şekilde uygulanmasıdır (Folger ve Konuvsky, 1989). Etkileşimsel adalet tarafların birbiriyle ilişki kurma üslubuna odaklanmaktadır (Bal-Taştan, 2013: 468). Etkileşimsel adalet, örgütün çalışanları ile iletişim tarafina yönelmiştir. Kaynakla adaletin alıcı arasındaki süreçte nezaket, dürüstlük, saygınlık gibi iletişimin yönleri ile ilintilidir (Tyler ve Bies, 1990). Etkileşimsel adalet aynı örgütün içinde yer alan yöneticilerle yönetilenlerin arasındaki etkileşime odaklanır (Folger ve Konovsky, 1989). Bu adalet türünde yöneticilerin kazanımların belirlenmesi ve işlemlerin yürütülmesi sürecinde yer alan işgörenlerine nasıl saygı gösterip değer verdiğine bakılmaktadır.

\section{3 İșten Ayrılma Niyeti}

Örgütler açısından insanların işe alınmasının yanı sıra bu işgörenlerin işte kalmalarının sağlanması da en önemli konulardandır. İşten ayrılma genel olarak, belirli bir süreci izleyerek çalışanın örgütten gönüllü ya da gönülsüz olarak ayrılmasını ifade etmektedir. Gönüllü işten ayrılma niyeti, bireyin kendi kararıyla ve kendi beklentileri neticesinde olurken; gönülsüz işten ayrılmaysa kişinin kendi kararının dışında örgütün isteğiyle gerçekleşmektedir (Mobley, 1982: 109). Zira çalışanların işten ayrılmaları, örgütte yetişmiş işgücünün kaybedilmesinden ötürü verimlilikle karlılık süreçlerini olumsuz şekilde etkilemektedir. Işsten ayrlma niyeti ise işgörenlerin çalış1lan örgütten ayrılma konusundaki bilinçli ve temkinli olarak verdikleri kararılardır. Çalışmalar göstermektedir ki, işten ayrılma niyeti, işten ayrılma eyleminin önceli olarak ortaya çıkmaktadır. Bu bağlamda, işten ayrılma nedeniyle ortaya çıkabilecek negatif durumların önlenmesi noktasında işten 
ayrılma niyetine ilişkin olarak araştırmacılarca çeşitli çalışmalar yapılmış olup, iş̧en ayrılma niyeti kavramı ile ilintili olarak birtakım tanımlamalar gerçekleştirilmiştir (Şahin, 2011: 277).

İşten ayrılma niyeti kavramı konusunda literatür de birbirine benzer pek çok tanımlama bulunmaktadır. Mobley (1982: 10) işten ayrılma niyetini, kişinin kısa zaman içerisinde işini bırakma arzusuna yönelik düşüncesi olarak belirtmiştir. Tett ve Meyer (1993: 262) ise işten ayrılma niyetini, kişinin işinden ayrılmayı planlı ve bilinçli biçimde arzulaması şeklinde tanımlamıştır. Barlett (1999: 70) işten ayrılma niyetini, örgütten ayrılmaya ilişkin bilinçli olarak karar alma ya da niyet etme biçiminde ifade etmiştir. Genel olarak örgütlerin işten ayrılma niyetine ilişkin algıları negatif yöndedir. Lakin bu konuyla ilintili temel nokta, örgütten kaç kişinin ayrıldığından ziyade, hangi personelin ayrıldığı olmalıdır (Allen ve Grifeth, 2000: 528). Dolayısıyla düşük performansa sahip personelin kendiliğinden işten ayrılmayı arzulaması, örgüt açısından pozitif bir katkı sağlayacaktır; fakat yüksek performansa sahip ve kilit çalışan rolündeki personelin işten ayrılmayı arzu etmesi, büyük bir maliyet unsuru olup, örgüte zarar verebilmektedir (Teoman, 2007: 34). Bu nedenle personelden işten ayrılma niyeti bulunanlara örgütün özenle dikkat etmesi gereklidir. Zira örgütlerin personele yönelik yaptıkları yatırımların toplam maliyetlerin içerisinde önemli bir paya sahip olmasıyla beraber, özünde geleceğe yönelik olarak gerçekleştirilen yatırım şeklinde değerlendirilmesi gereklidir (Alexander vd., 1994: 518).

İşten ayrılma niyetini etkileyen birtakım faktörler bulunmaktadır. Bu faktörler genel olarak işle ilgili faktörler, bireysel faktörler ve dış faktörler şeklinde ifade edilmektedir (Cotton ve Tuttle, 1986). Bunlardan işle ilgili faktörleri Cotton ve Tuttle (1986) ödemeler, iş performans1, rol netliği, görev tekrarı, genel iş tatmini, ödemeye ilişkin tatmin, işin kendisine ilişkin tatmin, denetime ilişkin tatmin, iş arkadaşlarına ilişkin tatmin ve örgütsel bağllık şeklinde ifade etmiş̧ir. Ayrıca Kaynak (1996: 37-38), işgörenlerin çok aşırı iş yükü, eğitim gibi nedenlerle zorlanması, işletmenin kuruluş yeri, çalışma şartlarının iyi olmaması, işin türü ve zorluğu, tatmin edici olmayan yönetim politikaları, örgütsel şartların boyutları, sosyal hizmetlerden yoksunluk, ulaşım, ücretlendirme sistemindeki bozukluk, üretim sürecinin yetersizliği gibi unsurların da işle ilgili işten ayrılma niyetini etkileyen unsurlardan olduğundan bahsetmiştir.

İşten ayrılma niyeti üzerinde etkisi bulunan bireysel faktörler yaş, bakmakla yükümlü olunan kişi sayısı, görev süresi, cinsiyet, biyografik bilgi, eğitim, medeni durum, yetenek ve kabiliyet, zekâ, davranış eğilimi ve beklentileri karşılama olarak otaya çıkarken. İşten ayrılma niyetine etki eden dış faktörleri ise, istihdam algılamaları, işsizlik oranı, katılım oranı, sendika ve birliklerin varlığı şeklinde siralamıştır (Cotton ve Tuttle,1986).

\subsection{Etik Liderlik, Örgütsel adalet ve İşsten Ayrılma Niyeti İlişskileri}

Literatürde etik liderlik ile örgütsel adalet arasındaki, etik liderlik ile işten ayrılma niyeti ve örgütsel adalet ile işten ayrılma niyeti arasındaki ilişkiye yönelik birtakım çalışmalar bulunmaktadır.

İşgörenlerin işe karşı tutumlarında en belirliyici unsur olarak ele alınan husus liderin tutum ve davranışlarıdır. Liderin oluşturduğu etik kültür ve iklim, çalışanların örgüte bağlanmasını artırmaktadır. Etik liderin sahip olduğu karakteristik özellikler (örneğin, adalet, güvenilirlik) ve değerler (örneğin, insanlar ve daha geniş toplumla ilgili endişeler, bencilik ve bireysel çıkarların yerine ortak hedefler), çalışanların işten ayrılma niyetlerini azalttığını göstermektedir (Brown ve Trevino, 2006b). Palanski ve arkadaşlarının Amerika Birleşik Devletlerinde yöneticilerin etik ve istismarcı davranışlarının iş tatmini, işten ayrılma niyeti ve iş arama davranışları üzerine etkilerini ölçmek için yaptıkları çalışmada istismarcı yönetimin tersine etik liderliğin iş tatmini artırıken, işten ayrılma niyetini azalttığı ortaya çıkmıştır (Palanski, vd.2014). Bir başka araştırmada da etik liderliğin işten ayrılma niyeti üzerine etkisinde çalışan sesi ilişkisine bakan Lam ve arkadaşları (2016), etik lider davranışlarının, çalışanların karar verme süreçlerine dâhil edilerek, fikirlerini paylaşacak, kendilerini değerli hissetmelerini sağlayacak iklimi ortaya çıkararak, çalışanların işten ayrılma niyetlerini düşürdüğünü kanıtlamışlardır (Lam, vd. 2016). Etik liderlik ve işten ayrılma niyeti 
arasındaki ilişkiye yönelik olarak gerçekleştirilen çalışmalarda, etik liderliğin işten ayrılma niyeti üzerinde negatif yönlü etkisi bulunduğu (örnek; Erdoğan-Arac1, 2019; Yanık ve Naktiyok, 2017; Lam, vd. 2016; Palanski, vd., 2014; Mayer vd., 2009; Breland vd., 2007) tespit edilmiştir. Bu bilgilerden hareketle, etik liderlik ile çalışanın işten ayrılma niyeti arasındaki ilişkiye yönelik geliştirilen hipotez şu şekilde ifade edilebilir.

\section{$H_{1}$ : Etik liderlik işten ayrllma niyetini negatif ilişski vardır.}

Etik değerlerin önem kazanmaya başlaması, işgörenlerin çalışma ortamlarında adil değerlendirilme ihtiyacını beraberinde getirmiş bu bağlamda yapılan bilimsel araştırmalarda etik liderlik özellikleri ile astların örgütsel adalet algıları arasında ilişkiler irdelenmeye başlanmıştır. Liderin davranışlarını örgütle bütünleştiren çalışanlar, adil, dürüst, doğru, eşit, tarafsız, hoşgörülü, hümanist ve ahlaklı davranışlar gösteren yöneticilerin, etik davranışlar sergileyerek, çalışma ortamında etik iklimi oluşturduğunu buna bağlı işgörenlerin birbirleri ile olan etkileşimlerini de olumlu yönde etkilediği görülmüştür (Turan, 2015; Akatay vd.2016). Etik lider etik kültür ve etik iklim oluştururken, buna uygun standartlar geliştirmekte, kaynakların dağılımı, ödül ve cezaların koşullarının neler olduğunu tanımlamaktadır (Yeşiltaş, vd.2012). Akatay ve arkadaşlarının (2016) Emniyet çalışanları üzerine yaptıkları çalışmada, EM yöneticilerin etik davranışlar sergilemesi, çalışanların adalet algılarını olumlu yönde etkilediği görülmüştür. Gül ve İncenin (2014) üniversitede çalışan idari personel üzerine yaptığ ç̧alışmada etik liderliğin iletişimsel alt boyutuyla dağıtımsal adalet arasında ve etik liderlğin iletişimsel ve karar verme boyutları ile etkileşimsel adalet arasında pozitif, güçlü ve anlamlı bir ilişki bulunmuştur. Yoldaş (2018) İstanbul'da faaliyet gösteren ilk ve ortaokullardaki yöneticilerin etik liderlik davranışların öğretmenlerin örgütsel adalet algısına etkilerini incelemiştir. Yapılan çalışmada öğretmenlerin etik liderlik algıları ile örgütsel adalet algıları arasında pozitif yönde anlamlı bir ilişki bulunduğu sonucuna ulaşılmıştır. Etik liderlik ve örgütsel adalet arasındaki ilişkiye yönelik olarak gerçekleştirilen çalışmalarda, etik liderliğin örgütsel adaletin üzerinde pozitif yönlü etkisi bulunduğu tespit edilmiştir (Yoldaş, 2018; Çitak, 2017; Akatay vd. 2016; İnak, 2016; Turan, 2015; Çiçek, 2014; Acar, 2011; Yıldırım, 2010; Uğurlu, 2009; Luria ve Yagil, 2008; Thompson, 2004). Literatürdeki önceki çalışmalarda elde edilen bu bulgular doğrultusunda aşağıdaki hipotezler oluşturulmuştur;

\section{$H_{2 a}$ : Etik liderlik dağıtım adalet algısını pozitif yönlü olarak etkiler.}

\section{$H_{2 b}$ : Etik liderlik etkileşim adalet algısını pozitif yönlü olarak etkiler.}

İşgörenlerin olumsuz adalet algıları sonucu en çok ortaya çıkan sonuçlardan bir tanesi işten ayrılma eğilimidir. İlgili yazında, işten ayrılmanın gerçekleşmesi kadar, işten ayrılma eğilimlerinin ortaya çıkmasının da adalet algıları ile ilgili olduğu belirtilmektedir. Bu bağlamda örgütsel adalet ve işten ayrılma niyeti arasındaki ilişkiye yönelik olarak gerçekleştirilen çalışmalarda, örgütsel adaletin işten ayrılma niyeti üzerinde negatif yönlü etkisi bulunduğu tespit edilmiştir (Kıratlı, 2015; Gieter vd., 2012; Günlük ve Özer, 2010; Pare ve Tremblay, 2007; Chang ve Dubinsky, 2005; Daileyl ve Kirk, 1992). Hassan, 2002 yılında yaptığı araştırmada çalışanların algıladığ 1 örgütsel adaletin bağlılığı arttırarak, işten ayrılma niyetini azalttı̆̆ 1 ve bu ilişkide dağıtım adaletinin diğer adalet algılarından fazla olduğu ortaya çıkmıştır (Hassan, 2002). Aghaei vd. (2012), dağıtım adaleti ile işten ayrılma niyeti arasında negatif ve anlamlı ilişkileri tespit etmişlerdir. Ulusal yazında da uluslararası yazını destekler şekilde işgörenlerin algıladıkları örgütsel adalet değerlemeleri olumlu oldukça işe bağlılıklarının, iş tatminilerinin ve iş performanslarının yükseldiği ve işten ayrılma niyetlerinin azaldığ1 belirlenmiştir (Bayarçelik ve Fındıklı, 2016; İşcan and Naktiyok 2004). Örücü ve Özafşarlıoğlu'nun (2013) tekstil işletmesinde yaptıkları çalışmada, örgütsel adalet algısı ile işten ayrılma niyeti arasında ters yönlü bir ilişkinin anlamlı düzeyde olduğu tespit edilmiştir. Literatürde bulunan çalışmalarda elde edilen bu bulgular doğrultusunda aşağıdaki hipotezler oluşturulmuştur; 
$H 3_{a}$ : Dă̆gtım adaleti algısı işten ayrılma niyetini negatif yönlü olarak etkiler.

$H_{3 b}$ : Etkileşim adaleti algısı işten ayrllma niyetini negatif yönlü olarak etkiler.

Bazı araştırmacılar (örneğin, Kirkman ve ark. 2009; Pillai ve ark. 1999) liderlerin çalışanların örgüt odaklı adalet algıları (dağıtımsal ve etkileşimsel adalet gibi) üzerinde önemli bir etkisi olması gerektiğini savunmaktadır. Etik liderler, kurumun adalet gibi etik standartlarına uygunluğunu koruyan ve teşvik eden ahlaki ajanlar gibi davrandıklarından, davranışlarının çalışanların örgütsel prosedürler ve sonuçlarla ilgili olarak adalet yargılamasında etkili rol oynaması beklenmektedir ( $\mathrm{Zu}$, vd. 2016). Yapılan yazın taramasında örgütsel çevrede etik ikliminin oluşması için etik lidere ihtiyaç olduğunu ayrıca çalışanların algıladıkları adalet duygusunun artmasının işe bağlılık ve iş tatmini artırken işten ayrılma niyetlerini azalttı̆ğ görülmektedir (Bayarçelik ve Fındıklı, 2016; İşcan and Naktiyok 2004). Bu doğrultuda algılanan örgütsel adaletin, etik liderliğin işten ayrılma niyeti değişkenleri ile arasındaki ilişkide aracı bir değişken olarak rol oynayabileceği varsayılmaktadır (Sökmen, 2019; Yanık ve Naktiyok, 2017; Lee, 2000). Literatürdeki önceki çalışmalarda elde edilen bu bulgular doğrultusunda aşağıdaki hipotez oluşturulmuştur; vardir.

$H_{4}$ : Etik liderliğin işten ayrlma niyeti üzerindeki etkisinde örgütsel adaletin aracı rolü

Tablo1: Araştırma Modeli

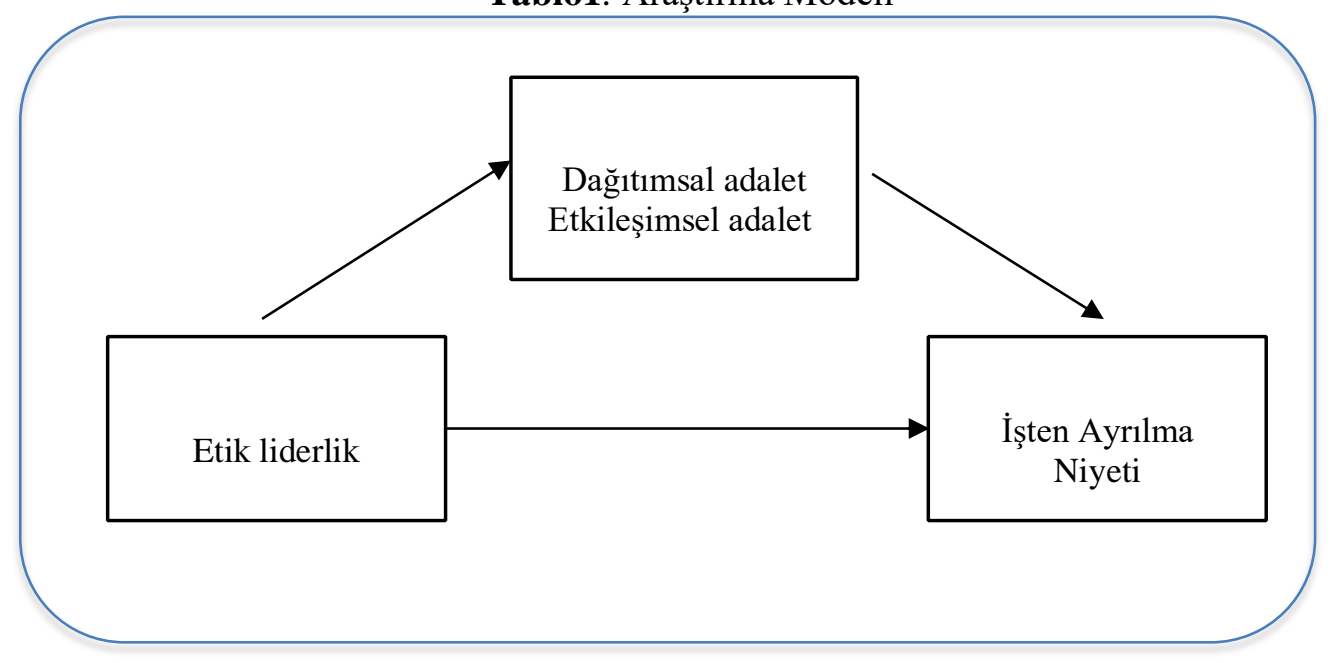

\section{Yöntem}

\subsection{Araştırmanın Amacı ve Kapsamı}

$\mathrm{Bu}$ çalışmanın amacı, yöneticilerin etik liderlik davranışlarının çalışanların işten ayrılma niyetlerine etkisini ve örgütsel adalet algılarının bu etkide oynadığı aracılık rolünü araştırmaktır.

\subsection{Evren ve Örneklem}

Araştırmanın evreni İstanbul bölgesinde yer alan kamu ve özel bankalardır. Araştırmada olasılığa dayalı olmayan örnekleme türü olan kolayda örnekleme yöntemi kullanılarak 700 kişiye anketler ulaştırılmıştır. Anketler hem online veri tabanlı hemde elden uygulanmıştır. Anketin ilk sayfasında araştırmanın amacı ve sonuçlarının gizliliğiyle ilgili bilgiler verilerek katılımcıların kişisel bilgilerinin anonim kalacağı ve araştırma dışında hiçbir amaç için kullanılmayacağı konusunda katılımcılar bilgilendirilmiştir. Ardından sırasıyla araştırma değişkenlerine yönelik 
sorular ve en sonunda da demografik bilgilere yer verilmiştir. Eksiksiz tamamlanan $390(\% 55,71)$ anket araştırma analizlerinde kullanılmıştır. Anketlerin geri dönüş oranı yüzde 56'dır. Anketi cevaplayan kişilerin \%55'ü kadın, \% 61'i 25-31 yaş aralığında ve tamamı üniversite veya üzeri eğitim seviyesine sahiptir. Bunun dışında \% 63'nün özel bankalarda çalışmakta, \%53'ünün şubelerde görev yapmakta, \%84'ünün 10 yıldan daha az süredir mevcut iş yerinde çalıştığı ve sadece \%13'ünün müdür/müdür yardımcısı pozisyonunda görev yaptığı görülmüştür.

\subsection{Veri Toplama Araçları ve Verilerin Analizi}

Araştırmada veriler üç ölçekten oluşan anket yöntemiyle toplanmıştır. Yararlanılan tüm ölçeklerin cevap seçenekleri "Kesinlikle Katılmıorum'dan (1)", "Kesinlikle Katıllyorum'a (5)" kadar uzanan 5'li likert ölçeğinden oluşmaktadır.

Etik Liderlik Ölçeği: Etik liderlik davranışını ölçmek için Brown, Trevino ve Harrison (2005) tarafından geliştirilen ve 10 ifadeden oluşan "Etik Lidelik Ölçeğii"inden faydalanılmıştır. Ölçek "Yöneticim, adil ve dengeli kararlar verir", "Yöneticim, etik kurallar çerçevesinde işlerin nasıl yapılacağına ilişkin model olur", "Yöneticim, etik kuralları ihlal eden çalışanlara yaptırım uygular" gibi sorulardan oluşmaktadır.

Örgütsel Adalet Ölçeği: İşgörenlerin örgütsel adalet algılarını ölçmek için Niehoff ve Moorman (1993) tarafindan geliştirilen "Örgütsel Adalet Ölçeği”" i kullanılmıştır. Ölçekte dağıtım adaletini ölçmeye yönelik 5 soru ve etkileşimsel adaleti ölçmeye yönelik 10 soru sorulmuştur. Ölçekte "İş yükümün adil olduğu kanısındayım", "Yöneticiler, işle ilgili kararları almadan önce bütün çalışanların görüşlerini alırlar", "İşimle ilgili kararlar alınırken yöneticilerim bir çalışan olarak haklarımı gözetirler" gibi sorulardan oluşmaktadır.

İşten Ayrılma Niyeti Ölçeği: Çalışanların işten ayrılma niyetlerinin belirlenmesinde Grandey'in (1999) üç sorudan oluşan "İşimden ayrılmayı sık sık düşünürüm", "Mevcut işimi bırakmaya niyetliyim", "Daha iyi bir iş için sürekli araştırma yapıyorum" ölçeği kullanılmıştır.

\subsection{Analizler}

Araştırma hipotezlerinin test edilmesinde yapısal eşitlik modellemesi kullanılmış (Bowen \& Guo, 2011), hem ölçüm hem de yapısal modelin değerlendirilmesinde kullanılan uyum değerleri olarak Hu ve Bentler'in (1999) önerileri temel alınmıştır. İlk olarak, değişkenlerin hipotez testinde kullanılabilmesinden emin olmak için kavramlara ait yapı geçerliliği ve güvenilirlik testi gerçekleştirilmiştir. Yapı geçerliliği için yakınsak ve ayrım geçerlilik testleri gerçekleştirilmiş̧ir (Fornell \& Larcker, 1981). Yakınsak geçerlilik sınaması için doğrulayıcı faktör analizi (DFA) kullanılmış, model uyumu ve maddelerin doğru örtük değişkenler altında yeterli faktör yüküne sahip olup olmadığı incelenmiştir. Ayrım geçerliliği ise, Hair vd. (2012) tavsiye ettiği şekilde, örtük değiş̧kenin açıklanan ortalama varyansının karekökünün, ilgili değişkenin diğer değişkenlerle olan korelasyon katsayısından büyük olup olmadığı incelenerek sınanmıştır. En sonunda da yapısal model oluşturularak hipotezler sınanmıştır. Dolaylı etki için Preaher ve Hayes (2008) önerileri temelinde 2000 örneklemli \%95 güven aralığında hata düzeltmeli bootstrapping yöntemi kullanılmıştır.

\section{Bulgular}

\subsection{Geçerlilik ve Güvenilirlik Sınamaları}

Yakınsak geçerliliğin sınanması için araştırmadaki tüm soruların ilgili örtük değişkenin ilişkilendirildiği DFA yapılmıştır. Örgütsel adaletin iki boyutu iki ayrı örtük değişken olarak modellenmiş, işlemsel adalet ayrışmamıştır. Böylece, dört faktörlü ve birincil düzey DFA modelinin oldukça iyi uyum gösterdiği bulunmuştur $\left(\chi^{2}=673.046, \mathrm{df}=269, \mathrm{CFI}=.949, \mathrm{TLI}=.943\right.$, RMSEA $=.064$, SRMR=.042). Model karşılaştırmaları yapıldığında bu modelin, örgütsel adalet maddelerinin tek faktör altında toplandığı 3 faktörlü modele göre istatistiksel olarak daha anlamlı olduğu görülmüştür 
$\left(\Delta \chi^{2}=12.2, \mathrm{df}=1, \mathrm{p}<.001\right)$. Ayrım geçerliliğinin sınanmas1 için dört örtük değişkenin çıkarılan ortalama varyans değerleri hesaplanmıştır. Bu değerlerin tamamının 50'den büyük olduğu ve korelasyon değerlerini aşmadığı görülmüştür. Bileşik güvenilirlik katsayıları da etik liderlik için .95, dağıtım adaleti için .89, etkileşim adaleti için .94, işten ayrılma niyeti için .92 olarak bulunmuştur. Böylece, dört faktörlü modelin ölçüm modeli olarak kabul edilebileceği görülmüş ve yapısal modelde bu dört örtük değişkenin kullanılması için yeterli destek bulunmuştur. Maddelere ait faktör yükleri Tablo 1'de, uyum değerleri Tablo 2'te, korelasyonlar Tablo 3'te verilmiştir.

Tablo 1: DFA Sonuçları

\begin{tabular}{ccc}
\hline Faktörler & Indicators & $\boldsymbol{\lambda}$ \\
\hline \multirow{3}{*}{ Etik Liderlik } & v61 & 0.852 \\
& v60 & 0.886 \\
& v59 & 0.899 \\
& v58 & 0.869 \\
& v57 & 0.882 \\
& v56 & 0.871 \\
& v55 & 0.522 \\
Dağıtım Adaleti & v53 & 0.765 \\
& v52 & 0.756 \\
& v61 & 0.852 \\
& v12 & 0.736 \\
& v13 & 0.748 \\
Etkileşim Adaleti & v14 & 0.822 \\
& v15 & 0.811 \\
& v16 & 0.831 \\
& v23 & 0.793 \\
& v24 & 0.835 \\
& v26 & 0.840 \\
& v27 & 0.818 \\
& v28 & 0.806 \\
& v29 & 0.844 \\
& v30 & 0.846 \\
& v31 & 0.751 \\
& v62 & 0.903 \\
& v63 & 0.956 \\
& v64 & 0.795 \\
& &
\end{tabular}

Tablo 2: Model Uyum Değerleri

\begin{tabular}{|c|c|c|c|c|c|c|}
\hline Modeller & $\chi^{2}$ & df & CFI & TLI & SRMR & RMSEA \\
\hline 4 Faktör Ölçüm Modeli & 673.046 & 269 & .949 & .943 & .042 & .064 \\
\hline 3 Faktör Ölçüm Modeli & 685.227 & 270 & .947 & .941 & .047 & .064 \\
\hline Yapisal Model & 704.201 & 270 & .945 & .939 & .059 & .066 \\
\hline Eşit Değerleri (Hu and Be & 1999) & & $>.90$ & $>.90$ & $<.08$ & $<.08$ \\
\hline
\end{tabular}


Tablo 3: Araştırma Değişkenlerine Ait Ortalamalar, Standart Sapmalar, Ortalama Çıkarılan Varyansın Karekökü ve Değişkenler Arası Korelasyonlar

\begin{tabular}{|c|c|c|c|c|c|c|}
\hline Variables & Mean & SD & 1 & 2 & 3 & 4 \\
\hline 1. Etik Liderlik & 3.29 & .939 & .819 & & & \\
\hline 2. Dağıtım Adaleti & 2.87 & .984 & .544 & .791 & & \\
\hline 3. Etkileşim Adaleti & 3.09 & .887 & .805 & .609 & .817 & \\
\hline 4. İşten Ayrılma Niyeti & 2.75 & .827 & -.418 & -.507 & -.518 & .887 \\
\hline
\end{tabular}

\subsection{Hipotez Testi}

Ölçüm modeli sonucunda elde edilen dört örtük değişkenli model kullanılarak etik liderliğin eksojen değişken, dağıtım adaleti, etkileşim adaleti ve işten ayrılma niyetinin endojen değişken olduğu, dağıtım ve etkileşim adaletinin aracı değişkenler olarak belirlendiği bir model kurulmuştur. Model uyum değerlerinin oldukça iyi olduğu görülmüştür $\left(\chi^{2}=704.201, \mathrm{df}=270 ; \mathrm{CFI}=.945\right.$; $\mathrm{TLI}=.939$, RMSEA=.066 SRMR=.059). Toplam açıklanan varyans (R2) işten ayrılma niyeti değiş̧keninde $\% 31$, dağıtım adaleti değişkeninde $\% 31$ ve etkileşim adaleti değişkeninde $\% 66$ olarak bulunmuştur. Korelasyon tablosu incelendiğinde etik liderlikle işten ayrılma arasında negatif ve anlamlı ilişki olduğu görülmüsstür $(r=-.418, \mathrm{p}<.001)$. Böylece $\mathrm{H} 1$ kabul edilmiştir. Model sonucunda etik liderliğin hem dağıtım adaleti $(\beta=.56, \mathrm{SH}=.050, \mathrm{p}<.001)$ hem de ektileşim adaleti $(\beta=.81$, $\mathrm{SH}=.044, \mathrm{p}<.001)$ üzerinde anlamlı direkt etkisinin bulunduğu, ancak işten ayrılma niyeti üzerinde anlamlı bir direkt etkisinin olmadığ $1(\beta=.07, \mathrm{SH}=.102, \mathrm{p}=.49)$ bulunmuştur. Böylece $\mathrm{H} 2 \mathrm{a}$ ve $\mathrm{H} 2 \mathrm{~b}$ kabul edilmiştir. Bunun yanısıra, hem dağtım adaletinin $(\beta=-.32, \mathrm{SH}=.079, \mathrm{p}<.001)$ hem de etkileşim adaletinin $(\beta=-.39, \mathrm{SH}=.119, \mathrm{p}<.001)$ işten ayrılma niyeti üzerinde anlamı negatif etkilerinin olduğu bulunmuştur. Böylece, $\mathrm{H} 3 \mathrm{a}$ ve $\mathrm{H} 3 \mathrm{~b}$ kabul edilmiştir. Etik liderliğin işten ayrılma niyeti üzerine dağıtım ve etkileşim adaleti üzerinden toplam dolaylı etkisinin anlamlı olduğu bulunmuştur ( $\gamma=-.50$, $\mathrm{SH}=.076,95 \% \mathrm{GA}=-.65:-.35)$. İki yolun dolaylı etkileri incelendiğinde ise etik liderliğin hem dağıtım adaleti üzerinden $(\gamma=-.19, \mathrm{SH}=.045,95 \% \mathrm{GA}=-.29:-.11)$ hem de etkileşim adaleti üzerinden $(\gamma=-.34$, $\mathrm{SE}=.087,95 \% \mathrm{GA}=-.51:-.17)$ dolaylı etkisinin anlamlı olduğu bulunmuştur. Bu sonuçlar hem dağıtım adaletinin hem de etkileşim adaletinin tam aracı değişken görevi gördüğünü göstermektedir. Böylece, Hipotez 4 kabul edilmiştir. Direkt ve dolaylı etki katsayıları Tablo 4 'te gösterilmiştir.

Tablo 4: Yapısal Model Direkt ve Dolaylı Etkiler

\begin{tabular}{|c|c|c|c|c|}
\hline Path & $\boldsymbol{\beta}$ & $\mathbf{S E}_{\beta}$ & $\gamma$ & $\mathbf{S E}_{\gamma}$ \\
\hline Etik Liderlik $\rightarrow$ Dağıtım Adaleti & .55 & $.050^{* * *}$ & & \\
\hline Etik Liderlik $\rightarrow$ Etkileşim Adaleti & .81 & $.044 * * *$ & & \\
\hline Dağıtım Adaleti $\rightarrow$ İşten Ayırılma Niyeti & -.32 & $.079 * * *$ & & \\
\hline Etkileşim Adaleti $\rightarrow$ İşten Ayrılma Niyeti & -.39 & .119 & & \\
\hline Etik Liderlik $\rightarrow$ Dağıtım Adaleti $\rightarrow$ İşten Ayrılma Niyeti & & & -.19 & .045 \\
\hline Etik Liderlik $\rightarrow$ Etkileşim Adaleti $\rightarrow$ İş̧ten Ayrılma Niyeti & & & -.34 & .087 \\
\hline
\end{tabular}




\section{Sonuç, Değerlendirme ve Öneriler}

$\mathrm{Bu}$ çalışmanın amacı, yöneticilerin etik liderlik davranışlarının çalışanların işten ayrılma niyetlerine etkisini ve örgütsel adalet algılarının bu etkide oynadığı aracılık rolünü incelemektir. Bu doğrultuda İstanbulda faaliyette bulunan kamu ve özel bankalarda görev yapan çalışanlardan elde edilen veriler ile yapısal eşitlik modeli kurularak analizler gerçekleşmiştir. Analiz sonuçlarına göre etik liderlik; dağıtımsal ve etkileşimsel adalet değişkenleri üzerinde pozitif yönlü anlamlı bir ilişkiye sahip iken, işten ayrılma niyeti üzerinde ise negatif yönlü anlamlı bir ilişkiye sahiptir (Yoldaş, 2018; Çitak, 2017; Akatay vd. 2016; İnak, 2016; Turan, 2015; Çiçek, 2014; Acar, 2011; Yıldırım, 2010; Uğurlu, 2009; Luria ve Yagil, 2008; Thompson, 2004). Ayrıca liderin etik davranışlar sergilemesi çalışanların işten ayrılma niyetlerini örgüt içinde algıladıkları adalet algının aracılığı ile azaltmaktadır. Araştırma sonuçları hem dağıtım adaletinin hem de etkileşim adaletinin tam aracı değişken görevi gördüğünü göstermektedir. Bulgular daha önceki çalışmaları destekler niteliktedir (Sökmen, 2019; Yanık ve Naktiyok, 2017; Lee, 2000). Etik lider davranışlarıyla örgüt içinde örnek olması gereken, işletmenin amaç ve hedeflerini gerçekleştirirken çalışanlarına doğru, adil, eşit, dürüst ve ne olursa olsun adaletten ve doğruluktan vazgeçmeyen davranışlarıyla etik iklimi oluşturandır. $\mathrm{Bu}$ durum, çalışanlar tarafindan örgüte ve yöneticilere karşı olumlu duygular oluşmasını sağlayacak, işe bağlılığı, güveni artırırken, örgütten ayrılma niyetini azaltacaktır. Yöneticilerin davranışları, astlarına tutumları, kaynakları ve ödülleri paylaşması ve dağıtması çalışanların çalışma ortamını adil algılamalarını ve örgüte hissedilen pozitif duyguları artırmakta, işten ayrılma niyetini azaltmaktadır. Bu çalışmanın en önemli kısıtı sadece bankacılık sektörününde uygulanmasıdır, gelecek çalışmalarda farklı hizmet ve üretim sektörlerinde birlikte uygulanarak sektörel farklar araştırılabilir. Ayrıca kültürel farklılıkların tespiti ve etik liderlik anlayışının daha iyi kavranabilinmesi için kültürler arası araştırmalar gelecek araştırmalara 1şık tutacaktır.

\section{Kaynakça}

Acar, G. (2011). Okul Yöneticilerinin Etik Liderlik Davranışlarının Beden Eğitimi Öğretmenlerinin Örgütsel Adalet ve Motivasyon Düzeyleriyle İlişkisi. Yayınlanmamış Doktora Tezi. Ankara: Gazi Üniversitesi EBE.

Adair, J. (2003). Etkili Motivasyon, S. Uyan (Çev.). İstanbul: Babıali Kültür Yayıncıllı̆ğ1.

Aghaei, N., M. Keivan ve S. Shahrbanian (2012). Relationship between Organizational Justice and Intention to Leave in Employees of Sport and Youth Head Office of Tehran. European Journal of Experimental Biology, 2 (5), s.1564-1570

Akatay, A., Yücekaya, P. ve Kısat, N. Ç. (2016). Yöneticilerin Etik Liderlik Davranışlarının, Örgütsel Adalet ve Sinizm Üzerine Etkileri: Çanakkale İl Emniyet Müdürlüğü’nde Bir Araştırma. Yönetim Bilimleri Dergisi, 14(28), 483-509. https://doi.org/10.11611/yead.493895

Alexander, J. A., Bloom, J. R. and Nuchols, B. A. (1994). Nursing Turnover and Hospital Efficiency: An Organization-Level Analysis. Industrial Relations, (33). https://doi.org/10.1111/j.1468232x.1994.tb00355.x

Allen, D. G. and Grifeth, R. W. (2000). Job Performance and Turnover: A Review and Integrative Multi-Route Model. Human Resource Management Review, 9(4), 525-548. https://doi.org/10.1016/s1053-4822(99)00032-7.

Bal-Taştan, S. (2013). Bir Negatif İş Davranışı Olarak Üretkenliğe Aykırı Davranışların İşyerinde Örgütsel Adaletsizlik ve Agresif Davranış Algıları ile İlişkisinde Psikolojik Güçlendirme, Benlik Değeri ve Sosyal Bütünleşmenin Düzenleyici Rolünün İncelenmesi. Sosyal ve Beşeri Bilimler Dergisi, 5(2), 466-481. https://doi.org/10.17494/ogusbd.51146. 
Bandura, A. (1977). Self-Efficacy: Toward a Unifying Theory of Behavioral Change. Psychological Review, 84(2), 191-215. https://doi.org/10.1037/0033-295x.84.2.191.

Barlett, K. R. (1999). The Relationship Between Training and Organizational Commitment in The Health Care Field. The Degree of Philosophy. Urbana: University of Illinois.

Bayarçelik, E. B., \& Fındıklı, M. M. A. İş Tatminin, Örgütsel Adaletin İşten Ayrılma Niyeti İlişkisindeki Aracılık Rolü. Beykent Üniversitesi Sosyal Bilimler Dergisi, 10(1). https://doi.org/10.18221/bujss.303365.

Beugre, C. D. (2002). Understanding Organizational Justice and Its Impact on Managing Employees: An African Perspective. Journal of Human Resource Management, 13(7), 1091-1104. https://doi.org/10.1080/09585190210131311.

Bowen, N. K., \& Guo, S. (2011). Structural equation modeling. Oxford University Press.

Breland, J., Treadway, D., Duke, A. and Adams, G. (2007). The Interactive Effect of Leader-Member Exchange and Political Skill on Subjective Career Success. Journal of Leadership and Organizational Studies, 13(3), 1-14. https://doi.org/10.1177/10717919070130030101.

Brown, M. E. (2007). Misconceptions of Ethical Leadership: How to Avoid Potential Pitfalls. Organizational Dynamics, 36(2), 140-155. https://doi.org/10.1016/j.orgdyn.2007.03.003.

Brown, M. E. and Trevino, L. K. (2006a). Socialized Charismatic Leadership, Values Congruence, and Deviance in Work Groups. Journal of Applied Psychology, 91(4), 954-962. https://doi.org/10.1037/0021-9010.91.4.954.

Brown, M. E. and Trevino, L. K. (2006b). Ethical Leadership: A Review and Future Directions.” The Leadership Quarterly, 17(6), 595-616. https://doi.org/10.1016/j.leaqua.2006.10.004.

Brown, M. E., Trevino, L. K. and Harrison, A. D. (2005). Ethical Leadership: A Social Learning Perspective for Construct Development and Testing. Organizational Behavior and Human Decision Processes, (97), 117-134. https://doi.org/10.1016/j.leaqua.2006.10.004.

Caldwell, C., Campbell, J. and Parks, C. D. (2001). Trustworthiness and Justice: An Integrative Perspective. Paper Presented at The Eighth Annual Conference on Ethics in Business, Chicago, IL, 187-199.

Chang, C. and Dubinsky, A. J. (2005). Organizational Justice in Sales Force: A Literature Review with Propositions. Journal of Business to Business Marketing, 12(1), 35-71. https://doi.org/10.1300/j033v12n01_03.

Charash, Y. C. and Spector, P. E. (2001). The Role of Justice in Organizations: A Meta Analysis. Organizational Behavior and Human Decision Processes, 86(2), 278-321. https://doi.org/10.1006/obhd.2001.2958.

Clayton, S. and Opotow, S. (2003). Justice and Identity: Changing Perspectives on What Is Fair. Personality and Social Psychology Review, 7(4), 298-310. https://doi.org/10.1006/obhd.2001.2958.

Cotton, J. L. and Tuttle, J. M. (1986). Employee Turnover: A Meta-Analysis and Review with Implications for Research. The Academy of Management Review, 11(1), 55-70. https://doi.org/10.2307/258331.

Çelik, M. ve Sarıtürk, M. (2012). Organizational Justice and Motivation Relationship: The Case of Adiyaman University. Istanbul Commerce University Journal of Social Science, (1), 353382 . 
Çetinkaya, M. ve Çimenci, S. (2014). Örgütsel Adalet Algısının Örgütsel Vatandaşlık Davranışı Üzerindeki Etkisi ve Örgütsel Özdeşleşmenin Aracılık Rolü: Yapısal Eşitlik Modeli Çalışması. Yönetim Bilimleri Dergisi, 12(23), 237-278. https://doi.org/10.18657/yonveek.335229.

Çiçek, H. (2014). Beden Eğitimi Öğretmenlerinin Çalışma Ortamlarındaki Örgütsel Adalet Düzeyinin Etik Liderlik Davranışlarına Etkisi (Kırıkkale İl Örneği). Yayınlanmamış Yüksek Lisans Tezi. Burdur: Mehmet Akif Ersoy Üniversitesi EBE. https://doi.org/10.20875/makusobed.594765.

Çitak, G. (2017). Yöneticilerin Etik Liderlik Davranışları ve Hemşirelerin Örgütsel Adalet Algıları. Yayınlanmamış Yüksek Lisans Tezi. Ankara: Gazi Üniversitesi SABE.

Çöp, S. (2008). Türkiye ve Polonya'da Turizm Sektörü Çalışanlarının Örgütsel Adalet ve Örgütsel Bağlılık Algılarına İlişkin Bir Uygulama. Yayınlanmamış Yüksek Lisans Tezi. Ankara: Gazi Üniversitesi EBE. https://doi.org/10.26650/imj.2019.87.0004.

Daft, R. and Marcic, D. (1998). Understanding Management. London: Harcourt.

Daileyl, R. C. and Kirk D. J. (1992) Distributive and Procedural Justice as Antecedents of Job Dissatifaction and Intent To Turnover. Human Relations, (45), 305-317. https://doi.org/10.1177/001872679204500306.

Davies, I. A. and Crane, A. (2003). Ethical Decision Making in Fair Trade Companies. Journal of Business Ethics, 45(1).

Efil, İ. (2010). İşletmelerde Yönetim ve Organizasyon, 11.Baskı. Bursa: Dora Yayınevi.

Erdoğan-Aracı, Ü. (2019). Etik Liderlik ile İşten Ayrılma Niyeti Arasındaki İlişkide Yapıcı Ses Çıkartma Davranışının Aracı Rolü. Turizm Akademik Dergisi, 6(1), 17-30. https://doi.org/10.31795/baunsobed.664016.

Eren E. (2012). Örgütsel Davranış ve Yönetim Psikolojisi, 13. Baskı. İstanbul: Beta Yayınları.

Folger, R. and Cronpanzano, R. (1998). Organizational Justice and Human Resource Management. U.S.A.: Sage Publications.

Folger, R. and Konuvsky, M. A. (1989). Effects of Procedural and Distributive Justice on Reaction to Pay Raise Decisions. Academy of Management Journal, 32(1), 23-53. https://doi.org/10.2307/256422.

Fornell, C., \& Larcker, D. F. (1981). Structural equation models with unobservable variables and measurement error: Algebra and statistics. Journal of Marketing Research, 18 (3), 328-388. https://doi.org/10.1177/002224378101800313.

Giap, B. ve Hackermeier, I. (2005). Organizational Citizenship Behavior and Perception of Organizational Justice in Student Jobs. Psychoplogy of Excellence Instructional Design, Job Analysis ve Job Design, 2-14.

Gieter, S. D., Cooman R. D., Hofmans J, Pepermans, R. and Jegers, M. (2012). Paylevel Satisfaction And Psychological Reward Satisfaction As Mediators Of The Organizational JusticeTurnover İntention Relationship. International Studies of Management \& Organization, (42), 50-67. https://doi.org/10.2753/imo0020-8825420103.

Greenberg, J. (1990), Organizational Justice: Yesterday, Today and Tomorrow. Journal of Management, 16(2), 399-432. https://doi.org/10.1177/014920639001600208.

Greenberg, J. (1996), The Quest For Justice: Essays and Experiments. U.S.A.: Sage Publications. 
Gül, H. ve Gökçe, H. (2008). Örgütsel Etik ve Bileşenleri. Süleyman Demirel Üniversitesi İktisadi ve İdari Bilimler Fakültesi Dergisi, 13(1), 377-389. https://doi.org/10.31671/dogus.2018.112.

Günlük, M. ve Özer, G. (2010). Örgütsel Adaletin Muhasebecilerin İş Memnuniyeti ve İşten Ayrılma Eğilimine Etkisi. Gaziantep Üniversitesi Sosyal Bilimler Dergisi, 9(2), 459-485. https://doi.org/10.11122/ijmeb.2013.9.20.305.

Hair, J. F., Sarstedt, M., Pieper, T. M., \& Ringle, C. M. (2012). The use of partial least squares structural equation modeling in strategic management research: a review of past practices and recommendations for future applications. Long range planning, 45(5-6), 320-340. https://doi.org/10.1016/j.lrp.2012.09.008.

Harvey, E. (2004). Liderlik ve Etik. Executive Excellence, 8(87), 13-27.

Hassan, A. (2002). Organızatıonal Justıce As A Determınant Of Organızatıonal Commıtment And Intention To Leave, Asian Academy Of Management Journal, 7(2), 55-66.

Helvacı, M. A. (2010). İlköğretim Okulu Yöneticilerinin Etik Liderlik Davranışı Gösterme Düzeyleri. Journal of World of Turks, 2(1), 391-410.

Hu, L. T., \& Bentler, P. M. (1998). Fit indices in covariance structure modeling: Sensitivity to underparameterized model misspecification. Psychological Methods, 3(4), 424. https://doi.org/10.1037/1082-989x.3.4.424.

Hwang, I. S. and Kuo, J. H. (2006). Effects of Job Satisfaction and Percevied Alternative Employement Opportunities on Turnover Intention - An Examination of Public Sector Organizations. Journal of American Academy of Business, 8(2).

İnak, A. (2016). Etik Liderlik Davranışının Örgütsel Adalet Üzerine Etkisi. Yayınlanmamış Yüksek Lisans Tezi. Nevşehir: Nevşehir Hacı Bektaş Veli Üniversitesi SBE. https://doi.org/10.30783/nevsosbilen.376138.

İşcan, Ö.F., Naktiyok, A., (2004). Perceptions Of Employees about Organizatonal Commitment and Justice as Determinants of Their Organizational Coherence. Ankara University Social Sciences Journal, 59(1), ss.181-281.

İyigün, Ö. N. (2012). Örgütsel Adalet: Kuramsal Bir Yaklaşım. İstanbul Ticaret Üniversitesi Sosyal Bilimler Dergisi, 1(21), 49-64.

James, K. (1993). The Social Context of Organizational Justice: Cultural, Intergroup and Structural Effects on Justice Behaviors and Perceptions, in Justice in The Workplace, Approaching Fairness in Human Resource Management, R. Cropanzano (Eds.). Erlbaum: Hillsdale, 2150. https://doi.org/10.1002/job.4030150512.

Kalshoven, K. and Boon, C. (2015). Ethical Leadership, Employee Well-Being, and Helping: The Moderating Role of Human Resource Management. Journal of Personnel Psychology, 11(1), 60-68. https://doi.org/10.1027/1866-5888/a000056.

Kaya, A. P. (2000). Sosyal Adaletin Teorik Çerçevesi Üzerine Bir Değerlendirme. Türk Ağır Sanayi ve Hizmet Sektörü Kamu İşverenleri Sendikası Yayını, (38), 229-244.

Kaya, M. (2008).Yükseköğretim Kurumlarında Çalışan Akademisyenlerin Çalışma Biçimlerinin Örgütsel Bağlılıklarına ve İşten Ayrılma Niyetlerine Etkisi. Yayınlanmamış Yüksek Lisans Tezi. Kocaeli: Kocaeli Üniversitesi SBE.

Kaynak, T. (1996). İnsan Kaynakları Planlaması, 2. Baskı. İstanbul: Alfa Basım Dağıtım. 
Kıratl1, M. (2015). Örgütsel Adaletin İşten Ayrılma Niyetine Etkisinde Örgütsel Güvenin Aracı Rolü: Ev Mobilyası Üretimi Yapan İşletmeler Üzerinde Bir Uygulama. Yayınlanmamış Yüksek Lisans Tezi. Ankara: Türk Hava Kurumu Üniversitesi SBE.

Kirkman, B. L., Chen, G., Farh, J. L., Chen, Z. X., \& Lowe, K. B. (2009). Individual power distance orientation and follower reactions to transformational leaders: A cross-level, cross-cultural examination. Academy of Management Journal, 52(4), 744-764. https://doi.org/10.1027/1866-5888/a000056.

Konovsky, M. A. (2000). Understanding Procedural Justice and Its Impact on Business Organizations. Journal of Management, 26(3), 498-511. https://doi.org/10.1177/014920630002600306.

Lam, L. W., Loi, R., Chan, K. W. and Liu, Y. (2016). Voice More and Stay Longer: How Ethical Leaders Influence Employee Voice and Exit Intentions. Business Ethics Quarterly, 26(3), 277-300. https://doi.org/10.1017/beq.2016.30.

Lee, H. R. (2000). An Empirical Study of Organizational Justice As a Mediator of The Relationships Among Leader-Member Exchange and Job Satisfaction, Organizational Commitment, and Turnover Intentions in The Lodging Industry. Unpublished Doctoral Dissertation. Virginia: Faculty of The Virginia Polytechnic Institute and State University.

Lu, C. S. and Lin, C. C. (2014). The Effects of Ethical Leadership and Ethical Climate on Employee Ethical Behavior in The International Port Context. Journal of Business Ethics, 124(2), 209223. https://doi.org/10.1007/s10551-013-1868-y.

Luria, G. ve Yagil, D. (2008). Procedural Justice, Ethical Climate and Service Outcomes in Restaurants. International Journal of Hospitality Management, 27(2), 276-283. https://doi.org/10.1016/j.ijhm.2007.07.022.

MacIntyre, A. (2001). Ethik'in Kısa Tarihi. İstanbul: Paradigma Yayınları.

Martin, K. D. and Cullen, J. B. (2006). Continuities and Extensions of Ethical Climate Theory: A Meta-Analytic Review. Journal of Business Ethics, 69(2), 175-194. https://doi.org/10.1007/s10551-006-9084-7.

Masterson, S. S., Lewis, K., Goldman, B.M. and Taylor, M. S. (2000). Integrating Justice and Social Exchange: The Differing Effects of Fair Procedures and Treatment on Work Relationships. Academy of Management Journal, 43(4), 738-748. https://doi.org/10.2307/1556364.

Mayer, D. M., Kuenzi, M. and Greenbaum, R. L. (2010). Examining The Link Between Ethical Leadership and Employee Misconduct: The Mediating Role of Ethical Climate. Journal of Business Ethics, (95), 7-16. https://doi.org/10.1007/s10551-011-0794-0.

Mayer, D., Kuenzi, M., Greenbaum, R., Bardes, M. and Salvador, R. B. (2009). How Low Does Ethical Leadership Flow? Test of A Trickledown Model. Organizational Behavior and Human Decision Processes, 108(1), 1-13. https://doi.org/10.1016/j.obhdp.2008.04.002.

Mobley, W. H. (1982). Some Unanswered Questions in Turnover and Withdrawal Research. Academy of Management Review, 7(1). https://doi.org/10.2307/257255.

Moorman, R. H. (1991) Relationship Between Organizational Justice and Organizational Citizenship Behaviors: Do Fairness Perceptions Influence Employee Citizenship? Journal of Applied Psychology, (76), 845-855. https://doi.org/10.1037/0021-9010.76.6.845.

Northouse, P. G. (2012). Leadership: Theory and Practice. Londra: Sage Publications. 
Örücü, E. ve Özafşarlıŏglu, S., (2013).The influence of organizational justice on the turnover intention:a study in the republic of South Africa. Mustafa Kemal University Social Sciences Journal,. 10 (23),335-358.

Palanski, M., Avey, J. B. and Jiraporn, N. (2014). The Effects of Ethical Leadership and Abusive Supervision on Job Search Behaviors in the Turnover Process. Journal of Business Ethics, 121(1), 135-146. https://doi.org/10.1007/s10551-013-1690-6.

Pare, G. and Tremblay, M. (2007). The Influence of High-Involvement Human Resources Practice, Organizational Commitment, and Citizenship Behaviors on Information Technology Professionals' Turnover Intentions. Group \& Organization Management, 32(3), 326-357. https://doi.org/10.1177/1059601106286875.

Piccolo, R. F., Greenbaum, R. L., Den Hartog, D. N. and Folger, R. (2010). The Relationship Between Ethical Leadership and Core Job Characteristics. Journal of Organizational Behavior, (31), 259-278. https://doi.org/10.1002/job.627.

Pillai, R., Schriesheim, C. A., \& Williams, E. S. (1999). Fairness perceptions and trust as mediators for transformational and Interactional leadership: A two-sample study. Journal of Management, 25(6), 897-933. https://doi.org/10.1177/014920639902500606.

Preacher, K. J., \& Hayes, A. F. (2004). SPSS and SAS procedures for estimating indirect effects in simple mediation models. Behavior Research Methods, Instruments, \& Computers, 36(4), 717-731. https://doi.org/10.3758/bf03206553.

Sabuncuoğlu, E. T. (2007). Eğitim, Örgütsel Bağlılık ve İşten Ayrılma Niyeti Arasındaki İlişkilerin İncelenmesi. Ege Akademik Bak1ş, 7(2). https://doi.org/10.21121/eab.2014418014.

Sökmen, A. (2019). Etik Liderlik, Örgütsel Güven, İş Tatmini ve İşten Ayrılma Niyeti İlişkisi: Bir Hastane İşletmesinde Araştırma. Üçüncü Sektör Sosyal Ekonomi Dergisi, 54(2), 917-934. https://doi.org/10.15659/3.sektor-sosyal-ekonomi.19.05.1123.

Söyük, S. (2007). Örgütsel Adaletin İş Tatmini Üzerine Etkisi ve İstanbul İlindeki Özel Hastanelerde Çalışan Hemşirelere Yönelik Bir Çalışma. Yayımlanmamış Doktora Tezi. İstanbul: İstanbul Üniversitesi SBE. https://doi.org/10.18506/anemon.452566.

Şahin, F. (2011). Lider Üye Etkileşimi ile İş̦en Ayrılma Niyeti Arasındaki İliş̧ki Üzerindeki Cinsiyetin Etkisi. Ege Akademik Bakış, 11(2). https://doi.org/10.21121/eab.2011219571.

Şahin, R. ve Kavas, E. (2016). Örgütsel Adalet ile Örgütsel Bağl1lık Arasındaki İlişkinin Belirlenmesinde Öğretmenlere Yönelik Bir Araştırma: Bayat Örneği. Süleyman Demirel Üniversitesi Vizyoner Dergisi, 7(14), 119-140. https://doi.org/10.21076/vizyoner.245975.

Teoman, D. D. (2007). Performans Değerlendirme Sürecinde Oluşan Adalet Algısı, Bu Algının İç, Dış ve Sosyal Ödüllerle Olan İlişkisinin İşten Ayrılma Niyeti’ne Olan Etkisi. Yayınlanmamış Yüksek Lisans Tezi. İstanbul: İstanbul Üniversitesi SBE.

Tett, R. P. and Meyer, J. P. (1993). Job Satisfaction, Organizational Commitment, Turnover Intention, and Turnover: Path Analyses Based on Meta Analytic Findings. Personnel Psychology, 46(2), 259-293. https://doi.org/10.1111/j.1744-6570.1993.tb00874.x.

Thompson, L. J. (2004). Moral Leadership in A Postmodern World. Journal of Leadership \& Organizational Studies, 11(1), 27-37.

Trevino, L. K., Weaver, G. R. and Reynolds, S. J. (2006). Behavioral Ethics in Organizations: A Review. Journal of management, 32(6), 951-990. 
Turan, E. D. (2015). Okul Öncesi Eğitimi Yöneticilerinin Etik Liderlik Davranışlarının Öğretmenlerin Örgütsel Adalet Algısı İle İlişkisi (Adıyaman İli Örneği). Yayınlanmamış Yüksek Lisans Tezi. Gaziantep: Zirve Üniversitesi SBE.

Turhan, M. (2007). Genel ve Mesleki Lise Müdürlerinin Etik Liderlik Davranışlarının Okullardaki Sosyal Adalet Üzerindeki Etkisi. Yayınlanmamış Doktora Tezi. Elazı̆̆: Fırat Üniversitesi SBE.

Tyler, T. R. and Bies, R. J. (1990). Beyond Formal Procedures: The Interpersonal Context of Procedural Justice, in J. S. Carroll (Eds.), Applied Social Psychology and Organizational Settings, 77-98. New Jersey: Erlbaum. https://doi.org/10.4324/9781315728377-4.

Uğurlu, C. T. (2009). İlköğretim Okulu Öğretmenlerinin Örgütsel Bağlılık Düzeylerine Yöneticilerin Etik Liderlik ve Örgütsel Adalet Davranışlarının Etkisi. Yayınlanmamış Yüksek Lisans Tezi. Malatya: İnönü Üniversitesi SBE.

Van Gils, S., Van Quaquebeke, N., Van Knippenberg, D., Van Dijke, M. and De Cremer, D. (2015). Ethical Leadership and Follower Organizational Deviance: The Moderating Role of Follower Moral Attentiveness. The Leadership Quarterly, 26(2), 190-203. https://doi.org/10.1016/j.leaqua.2014.08.005.

Werner, I. (1993). Liderlik ve Yönetim. İstanbul: Rota Yayınları.

Xu, A. J., Loi, R., \& Ngo, H. Y. (2016). Ethical leadership behavior and employee justice perceptions: The mediating role of trust in organization. Journal of Business Ethics, 134(3), 493-504. https://doi.org/10.1007/s10551-014-2457-4.

Yanık, O. ve Naktiyok, A. (2017). Etik (Ahlaki) Liderliğin Çalışanlanın İş Tatminine, Örgütsel Bağlılığına ve İşten Ayrılma Niyetine Etkisinde Örgütsel Güven ve Örgütsel Adalet Algısının Aracı Rolü. Bartın Üniversitesi İktisadi ve İdari Bilimler Fakültesi Dergisi, 8(15), 297-324.

Yeşiltaş, M., Çeken, H. ve Sormaz, Ü.(2012). Etik Liderlik Ve Örgütsel Adaletin Örgütsel Sapma Davranışları Üzerindeki Etkisi”, Muğla Üniversitesi, Sosyal Bilimler Enstitüsü Dergisi, 28, 18-38.

Yıldırım, A. (2010). Etik Liderlik ve Örgütsel Adalet İlişkisi Üzerine Bir Uygulama. Yayınlanmamış Yüksek Lisans Tezi. Karaman: Karamanoğlu Mehmet Bey Üniversitesi, SBE.

Yoldaş, A. (2018). Okul Yöneticilerinin Etik Liderlik Davranışlarının Öğretmenlerin Örgütsel Adalet Algıları Üzerine Etkilerinin İncelenmesi. Yayınlanmamış Yüksek Lisans Tezi. İstanbul: Bahçeşehir Üniversitesi SBE.

Yücel, R. ve Çiftçi, G. E. (2012). İşgörenin İş Etiği Davranış Algısı: Kamu Kurumunda Bir Uygulama. 11. Ulusal İşletmecilik Kongresi Bildiriler Kitab1, 927-932. 